\title{
Interactive Multimedia with Episodic Mapping Strategy for Teaching Short Story Writing to Grade XI
}

\author{
Hemas Haryas Harja Susetya*; Tadkiroatun Musfiroh \\ ${ }^{1}$ Postgraduate Student, Yogyakarta State University, Indonesia \\ ${ }^{2}$ Lecturer of Yogyakarta State University, Indonesia \\ Email: hemas.haryas@gmail.com
}

http://dx.doi.org/10.18415/ijmmu.v5i4.432

\begin{abstract}
This research was conducted to find out the results of the initial trials of interactive multimedia for learning to write short stories for eleventh grade high school students. This research is a development research that refers to the step of Borg \& Gall's development model, which is carried out through several stages, namely: 1) needs analysis; 2) planning; 3) the development of several initial products, and 4) trials. The subject of field trials was 15 students. Data was collected by questionnaire of product trials to determine the response of students after using interactive multimedia in learning to write short stories developed. The results of the research are as follows: 1) The needs include the availability of learning media to write short stories that are new, interesting, appropriate, facilitate and motivate students to carry out short story writing learning. The weakness of students is that they are less able to find and develop ideas into several good paragraphs. The desire of teachers and students is the existence of learning media that can help students in writing short stories; 2) This interactive multimedia development product consists of short story text material. This strategy episodic mapping can really help students develop ideas because in this episodic mapping students are guided to determine intrinsic elements in short stories; 3 ) The final product fulfills the qualification of product feasibility as indicated by the results of the student response questionnaire that interactive multimedia with strategy episodic mapping is developed on the aspect of display quality in the "good" category with a score of 4.00, on the quality aspect of product presentation with the category "good "Score 4.00, and product benefits with a score of 4.3" good "category. From the results of interactive multimedia validation with strategy episodic mapping for learning to write short stories, it is very helpful for students to write short stories. Interactive multimedia with this strategy episodic mapping can be an alternative source of learning in writing short stories.
\end{abstract}

Keywords: Interactive Multimedia; Episodic Mapping Strategy; Short Story Writing

\section{Introduction}

Learning media play a role in supporting the success of learning activities. The use of properly designed learning media will have an effect on better learning outcomes. Media can be used to develop students' ability to dig up information and understand the learning material taught. Learning media is also 
a supporter of the smooth learning process, namely by the establishment of learning objectives. Many education practitioners realize that the use of learning media is very helpful for learning activities, especially to improve student achievement. However, in its implementation there are not many teachers who use it in classroom learning. The limitations of learning media and the weakness of teachers in creating media is one of the reasons for the weak learning achievement of students. The interactive multimedia development model was also revealed by Rob. Phillips in Winarno., et al (2009: 23) which includes four stages. These stages are: design (design), develop (development), evaluate (evaluation), and the last stage is implemented (implementation). Luther in Ariesto, Hadi Sutopo (2003) mentions that there are 6 stages of multimedia development, namely concept (concept making), design (design), collecting material (collection of materials), assembly (assembly), testing (testing), and distribution (distribution).

Indonesian learning for high school in the 2013 curriculum is text-based learning. The presence of the 2013 high school curriculum brought many changes, especially in the content of Indonesian language subjects. Through this text-based learning, students will be faced with activities that will practice writing skills. Hope in this text-based learning is so that students are able to master and use various types of texts learned in real life. The teacher's challenge is to deliver material about various types of texts to students creatively and innovatively. One of them is by developing learning media to generate motivation as well as students' understanding of the expected competencies.

Learning to write short stories aims to make students have the ability to write, especially writing short stories. Writing is the highest level among other language skills. Writing activity is an activity that develops thinking power by collecting writing material, expressing ideas in the mind and then explaining them through writing in a coherent and systematic language so that it can be understood by others. By writing, students are expected to be able to express ideas clearly, logically, and systematically in accordance with the context and communication needs. Many difficulties faced by participants in writing. For example, students have ideas, but it is difficult to start writing or when the writing process has been carried out, he loses the idea of continuing his writing. Another form of difficulty is the difficulty of developing language so that it becomes an interesting writing. Especially if it is not supported by the creativity of teachers in facilitating students' writing activities. These innovations can be in the form of empowering learning components, including creative teachers, proactive students, learning objectives that are tailored to the times and challenges, diverse learning materials, varied learning methods, fun learning media, and appropriate learning evaluations.

The use of interactive multimedia with strategy is episodic mapping expected to be a solution to improve short story writing skills. In addition, it can support learning to write short stories to make it easier, effective, efficient and fun so that students' imagination and creativity can be explored more. One of the media that is much in demand by students, especially high school students is the media in the form of images, media images included in visual media. These media channel messages and information through visual symbols. Interactive multimedia in Indonesian language learning here has the advantage that it can make Indonesian language learning interesting, namely the interactive multimedia display is more attractive, varied, and attractive and has better and more realistic picture quality.

Therefore, it is necessary to develop learning resources in the form of learning media that can be used by students to study independently. This learning media is developed with certain strategies that can increase students' interests and abilities in short story writing activities. This learning media is arranged based on strategy steps episodic mapping, so that it can stimulate students in writing short stories. The language used is simple and communicative, so it is easily understood by students. 


\section{Literature Review a. Multimedia Learning}

The Development in the realm of Educational Technology includes printing technology, audio visual technology, computer-based technology, and integrated technology. Learning media in this case is included in the development area. Whereas in more detail, the multimedia category is included in computer-based technology. Computer-based technology basically displays information to learners through impressions on the monitor. Various computer applications are usually called "computer-based instruction (CBI)", "computer assisted instruction (CAI)", or "computer-managing instruction (CMI)".

Technological developments have had a great impact on various other areas of life, including education. Technology is expected to help improve the quality of education. One of the uses of technology in education is the creation of multimedia that can be used by teachers to help them deliver subject matter to students. According to Rahman and Amri (2013: 133), the use of computers in the learning process includes the terms CAI and CMI used in computer learning activities. Making multimedia is of course not arbitrary, so a development procedure is needed as a guide. For a long time, many experts in education have developed various multimedia development models that can be used by teachers as guidelines. One of the multimedia development models was designed by Alessi and Trollip (2001). Alessi and Trollip stated that in developing learning multimedia there are three phases, namely the planning, design, and develop phases. Each stage contains steps that must be taken to develop a multimedia.

\section{b. Short Story Writing Learning with Episodic Mapping Strategy}

The scope of learning Indonesian language and literature includes language learning and literature. It includes aspects of listening, speaking, writing and reading. One aspect that needs to be considered for students' creativity in literature is the aspect of writing. Nurgiyantoro (2010: 35) states that the incorporation of literary works into Indonesian language teaching is reasonable and understandable because language is a means of literary pronunciation, language is one of the most important forms of literature because the form of literature is language. Literature is a work of art that provides language with elements of outstanding beauty such as short stories.

This strategy according to Davis \& Mc Pherson (via Wiesendanger., 2001: 88) teaches knowledge of the structure of text, to gain the ability to follow the main structure in a story, such as setting (place and when), storyline or plot, themes, problems and problem solving. This is based on the idea that stories contain several big ideas that follow certain structures. Knowledge of the structure of the text helps students make a clearer and more focused storyline. Episodic mapping can be used by students in a variety of low achievement abilities, average and superior to this strategy. This allows students to map related story elements in a short story and help students visualize story episodes and more focused student imaginations.

In the 2013 curriculum, the Indonesian language competence standard is a minimum qualification of students' abilities which describes the mastery of knowledge, language skills, and a positive attitude towards Indonesian language and literature. Learning to write short stories is taught in SMA XI even semester. With these competency standards students are expected to be able to write short stories according to their abilities. Learning to write short stories is literary learning in schools that aims to train students' abilities in aspects of writing literary works. One of the techniques for writing short stories is to engineer a series of stories to be unique, new and of course second to none. 


\section{Methodology}

This type of research is research and development or known as Research and Development ( $\mathrm{R} \&$ D), which is a process used to develop and validate products used in education (Borg \& Gall, 1983: 772). The product developed in this study is the development of interactive multimedia with strategies episodic mapping for learning to write short stories for eleventh grade students. The research model used in this study is Research and Development ( $\mathrm{R} \& \mathrm{D}$ ) proposed by Borg and Gall. In the product testing phase to determine the feasibility level of the initial draft produced from the development stage so that later if improvements are made to improve the product in the form of learning media. The subjects in this development study were high school students of class XI. Data collection instruments consist of two instruments, namely (1) questionnaire and (2) interview guidelines. The purpose of using this questionnaire is for the initial review before the product trial. This review is carried out to find out students' knowledge of the product to be tested and to get an initial picture of the product to be developed. Questionnaire or questionnaire is a data collection technique that is done by giving a set of questions or written statements to the respondent to answer.

\section{Result}

Based on the results of the initial trial conducted at SMA 1 Gending which was attended by 15 students. The selection of fifteen students is carried out by teachers who teach Indonesian class XI subjects. Fifteen of these students consist of five upper groups, five middle groups, and five lower groups. This initial trial data is in the form of students on interactive multimedia with an strategy episodic mapping learning for learning to write short stories tested on them. The data of the students' responses in the form of scores are converted into five scales. The results of the conversion of scores to a scale of five can be seen in Table 1 .

Table 1 Summary of initial test results

\begin{tabular}{cccccc}
\hline No. & Aspects assessed & Score & $\begin{array}{c}\text { Average } \\
\text { Score }\end{array}$ & Score Criteria Interval & Category \\
\hline 1. & Display & 31.93 & 4.00 & $3.402<\bar{X} \leq 4.206$ & Good \\
2. & Presentation & 19.93 & 4.00 & $3.402<\bar{X} \leq 4.206$ & Good \\
3. & Benefits & 8.6 & 4.30 & $\bar{X} \geq 4.206$ & Very Good \\
\hline
\end{tabular}

Test Small group trials conducted on 15 students have the aim of collecting information in the form of student responses that can be used as material to improve products in the next revision. The response of students to interactive multimedia is aimed at three aspects, namely aspects of product display, aspects of product presentation, and aspects of product benefits. Based on the data in Table 4 it is known that the responses of students to this interactive multimedia product from the aspect of product quality display that get an average score of 4 , from the quality aspect of product presentation obtain an average score of 4 , and from the aspect of product benefits obtain an average score 4.3.

Analysis of the students' initial trial data was used for media practicality assessment based on student response questionnaires during implementation. The reason students enjoy this development product, that is interactive multimedia is made very interesting and entertaining so that students become motivated to write short stories because in this interactive multimedia plus an strategy episodic mapping 
that will help stimulate students in writing short stories. Interactive learning media can increase learners' interest and motivation to learn certain material. As stated which states that one of the role of learning media is a growing interest and motivation to learn, because interactive media will increase the enthusiasm of learners to be involved in all learning processes, both individuals and groups.

\section{Discussion}

Interactive multimedia for learning to write short stories has been developed. Media development results that have been tried out to students. The responses of students consist of aspects of display quality, product presentation and product benefits. Students in the initial trial generally gave positive responses with good and very good criteria for the three aspects of media quality developed. The findings of the initial trial results revealed significant differences in learning outcomes before and after implementing learning with interactive multimedia with strategies episodic mapping for learning to write short stories. The real difference shows that the media developed is effectively applied in learning to write short stories for students in class XI in SMAN 1 Dringu and SMAN 1 Gending. Thus, based on the final study above it can be said that interactive multimedia products for learning to write short stories that have been compiled and tested in the field are good and feasible products to be used in learning to write short stories for students of class XI SMA. The final product of this development product is interactive multimedia consisting of material for learning to write short stories for students of class XI SMA which are packaged in CD (Compact Disc).

Based on the results of the initial trials, it can be concluded that the product is suitable to be used as a learning medium to help learning activities in short story writing material, but based on the results that are less than optimal comments and suggestions from the initial trials indicate that there are some parts that need improvement. Therefore, the researcher provided training with an strategy scheme episodic mapping to facilitate writing short stories. The following is a view of the material before being revised and after being revised.

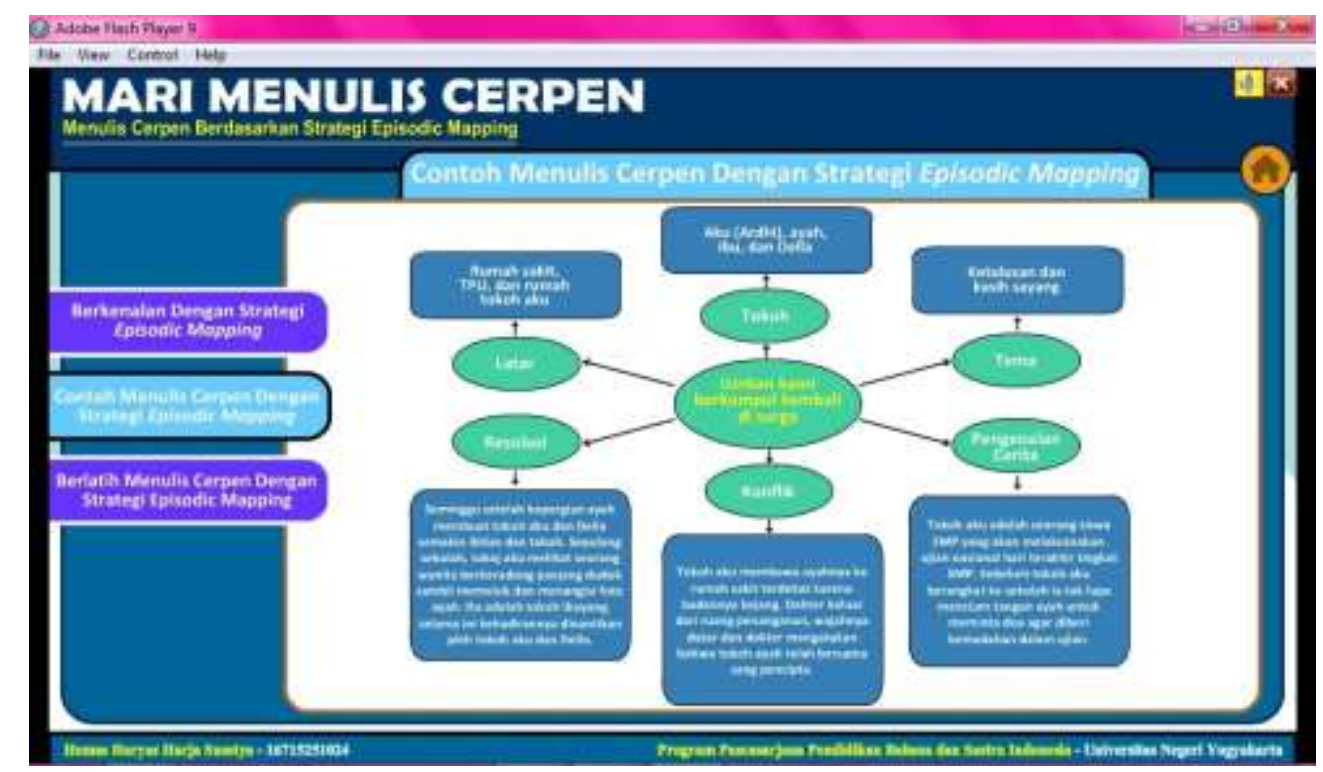

Fig. 1 Display of material before revision 


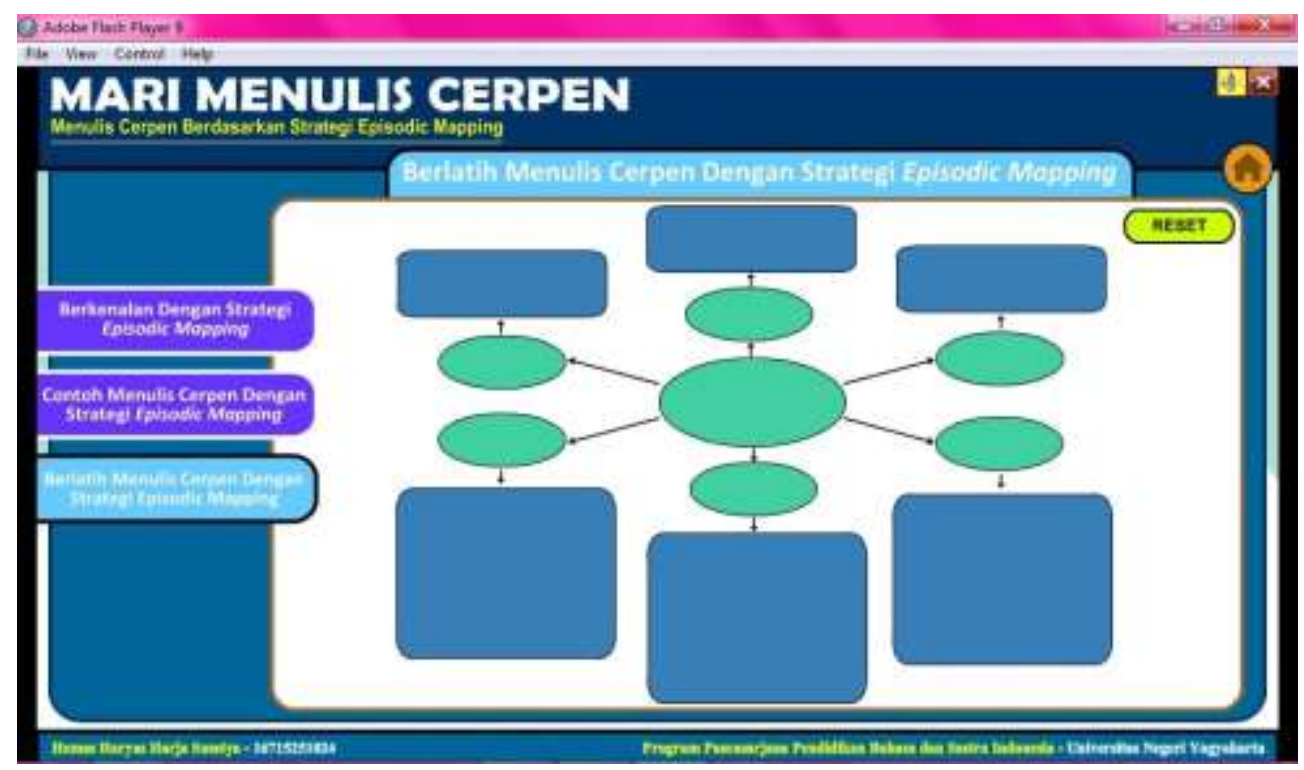

Fig. 2 Display of material after revision

\section{Conclusion}

Based on the results of the research and discussion, the following results are described related to the Development of Interactive Multimedia with Strategies Episodic mapping for Learning to Write Short Stories of Class XI High School Students using Bob \& Gall development model adaptation. Research and development of interactive multimedia as a learning media for writing short stories for students of class XI SMA. Based on the results of the initial trial of the students as a whole interactive multimedia with episodic mapping strategy to write short stories overall get a score of 4.00 from the aspect of appearance, the presentation aspect gets a score of 4.00, and the benefit aspect gets a score of 4.3. From the results of the initial interactive multimedia test scores, including media that are in good category and based on the advice of media experts and interactive multimedia material, it is ready to be tested on high school students in class XI. Based on the conclusions above, generally "Interactive Multimedia with Strategy Episodic Mapping for Short Story Writing Learning" is either good or valid as an alternative learning media, especially in short story writing material. The impression of students in this interactive multimedia they feel entertained and motivated to learn Indonesian language especially in learning to write short stories, in accordance with the benefits of the media in learning.

\section{References}

Alessi, Stephen M., dan Stanley R. Trollip. (2001). Multimedia for Learning Methods and Development: Third Edition. Massachusetts: Allyn and Bacon A. Pearson Company.

Ariesto Hadi Sutopo. (2003). Multimedia Interaktif dengan Flash. Yogyakarta: Graha Ilmu.

Borg, Walter R. and Meredith Damien Gall. (1983). Educational Research an Introduction. Fourth Edition. New York \& London: Lungman.

Nurgiyantoro, Burhan. (2010). Teori Pengkajian Fiksi. Yogyakarta: Gadjah Mada University Press. 
Rahman, M dan Amri, S. (2013). Stategi dan Desain Pengembangan Sistem Pembelajaran. Jakarta. Prestasi Pustakarya.

Wiesendanger, Katherine D. (2001). Strategies for Literacy Education. New Jersey: Merill Prentice Hall.

Winarno, dkk. (2009). Teknik Evaluasi Multimedia Pembelajaran. Malang: Genius Prima Media.

\section{Copyrights}

Copyright for this article is retained by the author(s), with first publication rights granted to the journal.

This is an open-access article distributed under the terms and conditions of the Creative Commons Attribution license (http://creativecommons.org/licenses/by/4.0/). 